\title{
O quinto resgate na zona do euro: A vez do Chipre ${ }^{1}$
}

\author{
The fifth bailout in the Eurozone: The time of Cyprus
}

Ariane de Oliveira Saraiva²

\section{RESUMO}

o paper tem o objetivo de apresentar as peculiaridades da crise financeira no Chipre e do seu pacote de resgate. $O$ país, reconhecidamente um paraíso fiscal e com um sistema bancário inchado, terá que proceder com o confisco de depósitos acima de € \$100 mil, o que representa mudança de atitude das instituições frente ao resgate e gera crise de confiança.

Palavras-chave: Chipre; Euro; crise financeira.

\begin{abstract}
This paper aims to provide an overview of the financial crisis unfolded in Cyprus and its rescue plan. The country, recognized as a fiscal paradise and with a bloated banking system, will have to proceed with the forfeiture of deposits, which represents a change of attitude towards the financial rescues and generates confidence crisis.
\end{abstract}

Key-words: Cyprus; euro; financial crisis.

Durante o primeiro semestre de 2013 mais um país da zona do Euro esteve em evidência em função da crise econômica que atinge a região. O Chipre, conhecido como um dos paraísos fiscais ${ }^{3}$ da Europa, utilizado especialmente por empresas e grandes depositantes individuais russos e ingleses, foi o mais recente caso a ser foco de protestos e preocupação depois de cinco anos de crise e de cinco resgates na zona euro.

O sistema bancário cipriota é cerca de sete vezes maior do que o PIB do Chipre ${ }^{4}$ e é, portanto, muito grande para o governo cipriota resgatá-lo sozinho. Assim,

\footnotetext{
${ }^{1}$ Artigo recebido em 03 de junho de 2013 e aprovado para publicação em 30 de setembro de 2013.

${ }^{2}$ Mestre em Ciência Política pela UFPR, Curitiba, Brasil.

${ }^{3}$ Embora não seja formalmente considerado um paraíso fiscal, o Chipre adotou um dos regimes fiscais mais favoráveis da Europa e taxas de remuneração acima do mercado com pouco controle quanto à origem do capital.

${ }^{4}$ PIB em 2012: US\$ 22,98 bilhões. Fonte: Banco Mundial.
} 
semelhante ao que ocorreu na da Irlanda, a causa da crise encontra-se em seus bancos, em função do regime fiscal adotado. Por sua vez, os bancos cipriotas estiveram fortemente expostos à crise financeira grega, pois estavam entre os maiores detentores de títulos gregos no continente, além de manter agências subsidiárias no país.

No final de 2012, os bancos russos tinham cerca de \$ 9 bilhões de euros em bancos cipriotas e as empresas cerca de $€ \$ 14$ bilhões, segundo a agência Moody's. Desta forma, cerca de dois terços dos depósitos estrangeiros no sistema bancário cipriota são russos. Dentre os depositantes pertecentes à zona do euro estão principalmente os gregos, que mudaram suas poupanças para Chipre por ser um refúgio seguro e para se proteger de sua própria crise financeira.

Essas duas características, um sistema bancário desproporcionalmente grande e predominância de depósitos estrangeiros, pesaram na decisisão dos credores internacionais. O Eurogrupo concordou em tomar uma decisão sobre o Chipre no final de março de 2013, depois de o novo governo cipriota do conservador Nicos Anastasiadis concordar com uma avaliação independente sobre seu setor financeiro, suspeito de ser utilizado pela máfia russa para lavagem de dinheiro. Embora o resgate do Chipre possa ser considerado pequeno, tem um gigantesco impacto em sua dívida pública, algo que o Fundo Monetário Internacional (FMI) não estava disposto a aceitar. Diante disso, e defendendo a taxação de depósitos, o Eurogrupo reduziu o resgate do Chipre a €\$10 bilhões, uma vez que inicialmente havia sido solicitado €\$ 17 bilhões. Dessa forma a dívida do país cairia a 100\% de seu PIB em 2020.

No dia 29 de março, após duas semanas com bancos fechados, dado o temor de fuga de capitais em massa, os cipriotas puderam retirar dinheiro nos caixas automáticos. Dias antes o Chipre obteve acordo prévio para receber empréstimo, previsto chegar a $€ \$ 10$ bilhões, da "Troika" - formada pelo Fundo Monetário Internacional (FMI), o Banco Central Europeu (BCE) e a Comissão Europeia (CE). Em 15 de maio, após diversas discussões sobre as condições do empréstimo e a aprovação pelo Parlamento do Chipre do plano de ajuste negociado com a troica, o FMI aprovou o empréstimo de $€ \$ 1$ bilhão e liberou uma parcela de 86 milhões, enquanto cerca de $€ \$ 9$ bilhões são do Mecanismo Europeu de Estabilidade (MEE). 
$\mathrm{Na}$ negociação, o Chipre aceitou uma tributação única sobre os depósitos superiores a $€ \$ 100$ mil de cerca de $40 \%$, posteriormente elevada para 47\%, conforme divulgado pelo seu Banco Central. Uma proposta anterior, de taxar os depósitos maiores de $€ \$ 20$ mil, já havia sido rejeitada. Portanto, a pressão aumentou à medida que se apressava para fechar um acordo de resgate e evitar um colapso financeiro. A série de contrapartidas do programa de resgate da troika inclui a reestruturação dos bancos com o objetivo de reduzir seu sistema - aumento de impostos e cortes salariais no setor público. Os depósitos inferiores a 100 mil euros, garantidos pelas leis europeias, serão transferidos para o maior banco do país, o Banco de Chipre, enquanto o estatal Laiki, o segundo maior, será fechado. Depósitos acima de €\$100 mil em ambos os bancos, serão congelados e usados para solucionar as dívidas do Laiki e recapitalizar o Banco do Chipre por meio de uma conversão de depósitos em ações.

A taxação, tal como está agora, deve levantar $€ \$ 4,2$ dos $€ \$ 5,8$ bilhões exigidos pelo BCE como garantia para o recebimento dos $€ \$ 10$ bilhões acordados para fortalecer a economia e recapitalizar os bancos, que estiveram fortemente expostos à dívida soberana grega e sofreram perdas significativas com a reestruturação da dívida. Ademais, o Chipre também foi atingido pela queda da demanda por seus produtos por parte da Grécia, principal parceiro comercial, desde que começou a recessão grega.

0 modelo adotado na reestruturação da dívida da Grécia e no resgate aos bancos do Chipre consiste no "bail-in". Sua proposta é fazer com que um banco insolvente seja recapitalizado com recursos do seu próprio passivo, sem a necessidade de aportes do governo. Desta forma, limita a exposição dos contribuintes e se opõe ao "bail-out", bastante noticiado na crise de 2008, por levar o Tesouro de diversos países a situações críticas em função dos recursos públicos injetados no sistema financeiro.

Para muitos analistas, o Chipre, ou mais especificamente o sul greco-cipriota da ilha, corre o risco de continuar um grande problema financeiro por causa do seu pacote de resgate. Analistas mais pessimistas acreditam que o país pode até mesmo necessitar de um segundo resgate, sobretudo porque as medidas exigidas podem gerar uma crise ainda mais profunda, inviabilizando a recuperação econômica.

A taxação sem precedentes e impopular para os titulares de depósitos em bancos cipriotas, muda as regras de resgate projetadas até então pela União Europeia 
(UE), FMI e BCE, embora não descumpra a garantia de depósitos bancários inferiores a $€ \$ 100$ mil, criada em 2008, depois da quebra do banco Lehman Brothers. Apesar de a situação cipriota e o seu plano de assistência configurar características específicas pela fraca regulamentação de seu sistema financeiro, geram como consequencia uma crise de confiança dos investidores e o temor de que tais medidas abram precedentes para situações futuras, além de ter exposto as divergências entre os países do bloco e a falta de liderança para lidar com a crise.

A título de informação e contextualização, a República de Chipre é membro da União Europeia desde 2004. Está localizada no Mar Mediterrâneo oriental ao sul da Turquia, cujo território é o mais próximo. Cerca de um terço do território, ao norte da ilha, foi ocupado pela Turquia em 1974, que então institui a República Turca de Chipre do Norte, nunca reconhecida pela ONU e reconhecida apenas pela própria Turquia. A ocupação ocorreu após 11 anos de violência entre as comunidades e um golpe de Estado de nacionalistas greco-cipriotas. A chamada "Questão cipriota" foi frequentemente incluída nas agendas das Assembleias Gerais da ONU e apesar do plano para a reunificação apoiado pelas Nações Unidas, um referendo de 2004 demonstrou que 76\% dos greco-cipriotas votaram contra.

\section{Referências Bibliográficas}

BITTENCOURT, A. BC ressuscita resgate de bancos com dinheiro publico. Disponível em: $\quad$ http://www.valor.com.br/valor-investe/casa-das-caldeiras/3112544/bcressuscita-resgate-de-bancos-com-dinheiro-publico\#ixzz2VBwZEjQQ. Acesso em $31 / 05 / 2013$

CHILETT, William. Chipre peligra como centro financeiro. Disponível em: http://www.realinstitutoelcano.org/wps/portal/rielcano/contenido?WCM_GLOBA L_CONTEXT=/elcano/elcano_es/zonas_es/economia+internacional/opinionchislett-chipre-centro-financiero. Acesso em 30/05/2013

CHIPRE (várias notícias). Disponível em: http://pt.euronews.com/search/. Acesso em $30 / 05 / 2013$ 
Parlamento do Chipre aprova plano de ajuste da troica. Disponível em: http://www.valor.com.br/internacional/3107092/parlamento-do-chipre-aprovaplano-30/de-ajuste-da-troica\#ixzz2VBx41PJA. Acesso em 31/05/2013

TORRES, J. L. A cronologia da crise bancária no Chipre. Disponível em: http://br.advfn.com/eventos/2013/crise-bancaria-no-chipre. Acesso em $31 / 05 / 2013$ 